\title{
PERLINDUNGAN HUKUM TERHADAP KEPENTINGAN PARA PIHAK DI DALAM MERGER BANK
}

\author{
Legal Protection of Interests of the Parties in the Bank Merger
}

\author{
Dani Amran Hakim \\ Universitas Diponegoro, Semarang \\ email: daniamranhakim@yahoo.com
}

\begin{abstract}
The legal protection of interests of the parties in the merger of banks, which is formulated into the problem as follows a) Is the legal basis for bank mergers? b) How is the legal protection of the parties in a bank merger? Merger is one of the company's development and growth. Merger is also one other alternative for capital investment through internal and organic growth. In banking mergers regulated in Law Number 10 of 1998. In the implementation of the merger must also consider the interests of the parties, namely, 1) the interests of the shareholders, 2) the interests of the depositors, 3 ) the interest of the bank employees, and 4) the interests of officials.
\end{abstract}

Keywords: Protection Law, the Parties, Bank Merger

\section{abstrak}

Perlindungan hukum terhadap kepentingan para pihak di dalam merger bank, yang dirumuskan menjadi permasalahan sebagai berikut a) Apakah dasar hukum merger bank? b) Bagaimana perlindungan hukum para pihak dalam merger bank? Merger merupakan salah satu pengembangan dan pertumbuhan perusahaan. Merger juga merupakan salah satu alternatif lain untuk melalui investasi modal pertumbuhan secara internal dan organis. Dalam perbankan merger diatur pada Undang-Undang No 10 Tahun 1998 tentang Perbankan. Dalam pelaksanaannya merger harus pula memperhatikan kepentingan para pihak, yaitu, 1) kepentingan para pemegang saham, 2) kepentingan para nasabah penyimpan dana, 3) kepentingan para pegawai bank, dan 4) kepentingan para pengurus.

\section{Kata Kunci: Perlindungan Hukum, Para Pihak, Merger Bank}

\section{A. Pendahuluan}

Merger atau penggabungan dilakukan oleh perusahaan-perusahaan untuk mencapai sasaran strategis dan sasaran finansial tertentu. Merger melibatkan penggabungan dua organisasi/perusahaan atau lebih yang 
seringkali berbeda dari segi karakter dan nilainya. ${ }^{1}$ Merger merupakan salah satu pengembangan dan pertumbuhan perusahaan. Merger juga merupakan salah satu alternatif lain untuk melalui investasi modal pertumbuhan secara internal dan organis. Dari waktu ke waktu, perusahaan-perusahaan lebih menyukai pertumbuhan eksternal dibandingkan pertumbuhan internal. ${ }^{2}$ Pasal 1 angka 9 Undang-Undang No. 40 Tahun 2007 tentang Perseroan Terbatas menentukan bahwa penggabungan adalah perbuatan hukum yang dilakukan oleh satu perseroan atau lebih untuk menggabungkan diri dengan perseroan lain yang telah ada yang mengakibatkan aktiva dan pasiva dari Perseroan yang menggabungkan diri beralih karena hukum kepada Perseroan yang menerima penggabungan dan selanjutnya status badan hukum Perseroan yang menggabungkan diri berakhir karena hukum.

Menghadapi persaingan usaha yang makin lama makin tajam di dunia bisnis, lebih-lebih di era globalisasi saat ini, perusahaan-peruahaan besar berupaya mencari jalan untuk meningkatkan efisiensinya dan apabila mungkin meningkatkan daya saing, size, dan kinerjanya termasuk perusahaan yang bergerak dalam bisnis perbankan. Namun bagi bank, di samping alasan-alasan tersebut, kepentingan bank untuk melakukan merger dan konsolidasi adalah untuk meningkatkan modalnya berkenaan dengan keharusan bank untuk memenuhi rasio kecukupan modal yang ditetapkan oleh Bank Indonesia. Alasan lain bank melakukan merger adalah untuk mengatasi keadaan bank yang bermasalah. ${ }^{3}$

Ada beberapa macam pihak yang berkepentingan pada perusahaan yang melakukan merger, yang memiliki kepentingan atas berhasilnya suatu merger. Mereka yang berkepentingan adalah para pemegang saham, para karyawan, masyarakat setempat dan perekonomian secara luas. ${ }^{4}$ Maka dari itu apabila perusahaan berniat melakukan merger haruslah mempertimbangkan kepentingan-kepentingan para pihak tersebut. Berdasarkan uraikan yang telah dijabarkan penulis tertarik untuk menulis tulisan dengan judul "Perlindungan Hukum Terhadap Kepentingan Para Pihak di dalam Merger Bank".

Berdasarkan latar belakang yang telah diuraikan di atas maka permasalahan dalam tulisan ini adalah 1) apakah dasar hukum merger bank?; dan 2) bagaimana perlindungan hukum para pihak dalam merger bank?

Permasalahan dalam tulisan ini dilatarbelakangi oleh sasaran analisis mengenai Merger Bank dalam peraturan perundang-undangan, dalam hal ini Undang-Undang Nomor 10 Tahun 1998 tentang Perubahan Atas Undang-

\footnotetext{
${ }^{1}$ Adrian Sutedi, Hukum Perbankan, (Jakarta: Sinar Grafika, 2007), hlm. 83.

${ }^{2}$ PS. Sudarsanam, The Essence of Mergers and Acquistions, Prentice HallEurope Ltd., 1995), hlm. 1.

${ }^{3}$ Op. Cit., Adrian Sutedi, hlm. 84.

${ }^{4}$ Ibid., hlm. 83.
} 
Undang Nomor 7 Tahun 1992 tentang Perbankan dan Undang-Undang Nomor 40 Tahun 2007 tentang Perseroan Terbatas serta juga peraturan lain yang menyangkut bahan kajian. Maka pendekatan yang digunakan adalah pendekatan perundang-undangan (statute approach). Statute approach merupakan metode dengan menggunakan pendekatan perundang-undangan, karena yang diteliti adalah berbagai aturan hukum yang menjadi fokus sekaligus tema sentral penelitian.

Metode pendekatan yang diterapkan dalam pelaksanaan penelitian ini adalah sebagai berikut:

1. pendekatan perundang-undangan (statute approach) berkaitan dengan aturan-aturan mengenai merger Bank di Indonesia dalam UndangUndang Nomor 10 Tahun 1998 tentang Perbankan dan Undang-Undang Nomor 40 Tahun 2007 tentang Perseroan Terbatas; dan

2. pendekatan konsep (conceptual approach), yaitu hendak menganalisis konsep dari merger Bank tersebut, serta dalam pelaksanaannya memberikan perlindungan hukum terhadap para pihak.

\section{B. Pembahasan}

\section{Pengertian Merger}

Istilah merger itu sendiri berasal dari bahasa Inggris, yaitu merger, yang berarti menggabungkan/memfusikan. Menurut Peraturan Pemerintah Nomor 28 Tahun 1999 tentang Merger, Konsolidasi, dan Akuisisi, pada Pasal 1 ayat (2) menyebutkan merger adalah; penggabungan dari dua bank atau lebih, dengan cara tetap mempertahankan berdirinya salah satu bank, dan membubarkan bank-bank lainnya tanpa melikuidasi terlebih dahulu.

Istilah merger menurut Kenneth M. Davidson adalah, "any transaction that forms one economic unit from two or more pervious ones", 5 yang berarti, suatu transaksi yang membentuk dua atau lebih perusahaan menjadi satu unit usaha. Menurut Munir Fuady, istilah merger ini dimaksudkan adalah sebagai suatu fusi atau absorpsi dari suatu benda atau hak benda atau hak lainnya. ${ }^{6}$ Secara umum dapat dikatakan bahwa dalam hal ini fusi atau absorpsi tersebut dilakukan oleh suatu subjek yang kurang penting dengan subjek lain yang lebih penting, dan subjek yang kurang tersebut kemudian membubarkan diri. Dengan demikian merger perusahaan berarti dua perusahaan melakukan fusi, di mana salah satunya akan lenyap dibubarkan. ${ }^{7}$

\footnotetext{
${ }^{5}$ John M Echols dan Hassan Shadily, Kamus Inggris-Indonesia, Cetakan XIX, (Jakarta: PT.Gramedia, 1990), hlm. 378.

${ }^{6}$ Munir Fuady, Hukum Tentang Merger, Cetakan ke-I, (Bandung: PT. Citra Aditya Bakti, 1999), Hlm. 2.

${ }^{7}$ Loc.Cit., Munir Fuady, hlm. 2 .
} 
Menurut Black's Law Dictionary, merger adalah fusion or absorption of one thing or right into another ${ }^{8}$, yang berarti fusi atau absorpsi tersebut dilakukan oleh suatu subjek yang kurang penting dengan subjek lain yang lebih penting. Subjek yang kurang penting itu kemudian membubarkan diri. Dengan demikian merger perusahaan berarti dua perusahaan melakukan fusi, di mana salah satu diantaranya akan lenyap (dibubarkan). Dalam istilah hukum perusahaan merger adalah tindakan penggabungan dua perusahaan sesuai dengan syarat-syarat yang ditetapkan oleh undang-undang, di mana satu dari beberapa perusahaan tetap bertahan dan yang lainnya hilang. ${ }^{9}$

Menurut A. Zen Purba dalam makalah merger dan akuisisi di Indonesia, yang dibawakan dalam seminar Undang-Undang Nomor 10 Tahun 1998 mengenai Merger dan Akuisisi di Jakarta tahun 1991 mengatakan, "Merger adalah penggabungan dua atau lebih perusahaan ke dalam salah satu dari mereka dan perusahaan yang bergabung membubarkan diri." Sedangkan Christian Wibisono, pada seminar yang sama memberikan pandangannya bahwa, "Merger adalah penggabungan dua badan usaha atau lebih yang relatif berimbang kekuatannya, sehingga terjadi kombinasi yang merupakan wadah bersama yang saling memperkuat. ${ }^{10}$

Di negara-negara asing terutama di negara-negara Anglo Saxon istilah merger adalah bentuk bangunan kerjasama, sedangkan di dalam Peraturan Pemerintah Nomor 27 Tahun 1998 dikenal dengan istilah penggabungan untuk merger. Menurut ketentuan Pasal 1 angka 1 PP Nomor 27 Tahun 1998 pengertian penggabungan perusahaan adalah: "Penggabungan adalah perbuatan hukum yang dilakukan oleh suatu Perseroan atau lebih untuk menggabungkan diri dengan Perseroan lainnya yang telah ada dan selanjutnya Perseroan yang menggabungkan dirinya menjadi bubar." Sedangkan pengertian merger dalam Undang-undang Nomor 10 Tahun 1998, Pasal 1 ayat 25 menyebutkan "Merger adalah penggabungan dari dua bank atau lebih dengan cara tetap mempertahankan berdirinya salah satu bank dan membubarkan bank-bank lainya dengan atau tanpa melikuidasi.

Perjanjian merupakan dokumen yang telah menjadi fondasi dan sekaligus pilar yang menyangga hubungan antara satu orang (pihak) dan orang (pihak lainnya) ${ }^{11}$, sebagaimana diakui dalam Pasal 1338 ayat (3) KUHPerdata yang mengatakan bahwa "Semua persetujuan yang dibuat secara sah berlaku sebagai undang-undang bagi mereka yang membuatnya".

\footnotetext{
${ }^{8}$ Henry Campbell Black, Black's Law Dictionary, (St. Paul Minn: West Publishing Co., 1991), hlm. 682.

${ }^{9}$ Ibid.

${ }^{10}$ Agus Daryanto, Meger Bank Indonesia (Beserta Akibat-Akibat Hukumnya), (Bogor: Ghalia Indonesia, 2004), hlm. 87.

${ }^{11}$ Cornelius Simanjuntak, dan Natalie Mulia, Merger Perusahaan Publik, (Bandung: PT Citra Aditya Bakti, 2006), hlm. 24.
} 
Pasal ini seolah-olah membuat suatu pernyataan yang mengizinkan dibuatnya perjanjian apa saja dan itu mengikat kedua belah pihak sebagaimana mengikatnya suatu undang-undang. Suatu perjanjian merger dalam merger perusahaan berbentuk Perseroan Terbatas (PT) sangat esensial dan besar kontribusi (sumbangan) hukumnya sebagai alat bukti. Seperti halnya dengan keberadaan (eksistensi) suatu Rapat Umum Pemegang Saham (RUPS) dalam proses merger yang mutlak harus ada, merger tidak akan dapat direalisasikan tanpa adanya suatu perjanjian merger.

Pada dasarnya penggabungan perusahaan pun juga harus memperhatikan berbagai faktor, sebagai pertimbangan apakah perusahaan tersebut layak untuk melakukan merger dengan perusahaan lain. Hal ini dapat kita lihat dari beberapa faktor seperti faktor produksi, faktor finansial, faktor pajak, faktor hukum, faktor SDM, dan lain-lain. Banyak perusahaan di Indonesia yang melakukan merger dalam rangka memajukan usahanya. Pada perusahaan yang melakukan merger, maka perusahaan tersebut akan melakukan "reorganisasi". Pengertian reorganisasi perusahaan dalam artian yang luas, ialah perubahan mengenai imbangan atau susunan tertentu, baik yang menyangkut struktur organisasi perusahaan maupun struktur modal dari suatu perusahaan. Pengertian Reorganisasi perusahaan dapat dibedakan menjadi tiga, yaitu : 1) Reorganisasi Yuridis, yaitu perubahan mengenai bentuk hukum dari suatu perusahaan atau badan usaha. 2) Reorganisasi Intern, yaitu perubahan mengenai bentuk atau struktur organisasi (organisasi intern) dari suatu perusahaan atau badan usaha. 3) Reorganisasi Finansial, ialah perubahan menyeluruh dari keseluruhan struktur modal dalam perusahaan. ${ }^{12}$ Kalau tabungan merupakan sumber dana untuk membiayai pembangunan ekonomi, maka tingkat perkembangan ekonomi lebih ditentukan oleh cara bagaimana dana-dana itu digunakan. Wiraswasta yang merupakan kunci yang memunyai kegiatan menentukan dalam pembangunan ekonomi. $^{13}$

\section{Dasar Hukum Merger Bank}

Undang-Undang Perbankan mengenal dua macam merger saham bank, yaitu secara sukarela dan imperatif. Merger sukarela adalah merger yang dilakukan secara sukarela oleh masing-masing pemegang saham bank yang akan melakukan merger atau dilakukan secara sukarela oleh pemegang saham bank yang akan diakuisisi sahamnya dan oleh pihak yang akan melakukan akuisisi saham bank tersebut. Adapun yang dimaksudkan dengan

12 Bambang Riyanto, Dasar-Dasar Perusahaan, (Yogyakarta: Yayasan Badan Penerbit Gadjah Mada, 1989), hlm. 240.

13 Irawan dan M. Suparmoko, Ekonomi Pembangunan, (Yogyakarta: BPFE Yogyakarta, 1992), hlm. 222. 
merger yang imperatif adalah merger yang merupakan pelaksanaan dari perintah Bank Indonesia dalam rangka menyelamatkan bank yang bermasalah. ${ }^{14}$

Pasal 28 Undang-Undang No. 10 Tahun 1998 tentang Perubahan Atas Undang-Undang No. 7 Tahun 1992 tentang Perbankan (selanjutnya disingkat UU Perbankan), mengatur mengenai merger sukarela. Sedangkan Pasal 37 ayat 2 mengtur mengenai merger imperatif. Menurut pasal 28 ayat 1 menyatakan bahwa merger, konsolidasi dan akuisisi wajib dahulu mendapat izin pimpinan Bank Indonesia. Mengingat ketentuan Pasal 10 jo. Pasal 7 huruf $\mathrm{b}$ dan $\mathrm{c}$ UU Perbankan, bank hanya boleh melakukan merger dan konsolidasi dengan perseroan yang berupa bank saja dan hanya boleh melakukan akuisisi perseroan bank dan perusahaan lain sepanjang usahanya di bidang keuangan.

Dari ketentuan Pasal 7 huruf b UU Perbankan itu dapat diketahui bahwa pelaksanaan akuisisi oleh suatu bank terhadap saham bank lain atau terhadap saham perusahaan lain di bidang keuangan harus dilakukan dengan memenuhi ketentuan yang ditetapkan oleh Bank Indonesia. Di samping harus dilaksanakan dengan ketentuan Pasal 28 UU Perbankan yang merupakan ketentuan khusus (lex specialis), juga harus diperhatikan ketentuan umum (lex generalis) yang diatur dalam Undang-Undang No. 40 Tahun 2007 tentang Perseroan Terbatas.

Menurut ketentuan Pasal 37 ayat 2 UU Perbankan, dalam hal suatu bank mengalami kesulitan yang membahayakan kelangsungan usahanya, maka Bank Indonesia dapat, antara lain, melakukan tindakan agar bank melakukan merger atau konsolidasi dengan bank lain atau bank dijual kepada pembeli yang bersedia mengambil alih seluruh kewajiban bank tersebut. Di samping harus memperhatikan ketentuan Pasal 28 UU Perbankan dan ketentuan-ketentuan Pasal 122-137 UU No. 40 Tahun 2007 UUPT, merger saham bank harus pula memperhatikan ketentuan Peraturan Pemerintah No. 28 Tahun 1999 tentang Merger, Konsolidasi dan Akuisisi Bank, yang membawa konsekuensi hukum sebagai berikut;

a. pemegang saham bank yang melakukan merger demi hukum (by operation of law) menjadi pemegang saham bank hasil merger; dan

b. aktiva dan pasiva bank yang melakukan merger beralih karena hukum kepada bank hasil merger.

Namun demikian, meskipun UU Perbankan memungkinkan dilakukannya merger antar bank, tetapi pemerintah tidak menginginkan bahwa merger tersebut akan menghasilkan berdirinya suatu bank baru yang sangat besar dilihat dari segi asetnya. Hal tersebut diatur oleh ketentuan

${ }^{14}$ Sutan Remy Sjahdeini, Merger Konsolidasi dan Akuisisi Bank, (Tidak Dipublikasikan, Tanpa Tahun), hlm. 5. 
Pasal 8 huruf b Peraturan Pemerintah No. 28 Tahun 1999 yang menentukan bahwa merger atau konsolidasi antar bank hanya dapat dilakukan dengan ketentuan pada saat terjadinya merger atau konsolidasi, jumlah aktiva bank hasil merger tidak melebihi $20 \%$ (dua puluh persen) dari jumlah aktiva (assets) seluruh Bank Umum di Indonesia. Selain itu mengenai tata cara pelaksanaan/prosedur merger bank, telah diatur dalam dua buat surat keputusan Bank Indonesia, yakni Surat Keputusan Bank Indonesia Nomor 32/51/KEP/DIR tanggal 14 Mei 1999 tentang Persyaratan dan Tata Cara Merger, Konsolidasi dan Akuisisi Bank Umum, serta Surat Keputusan Bank Indonesia Nomor 32/52/KEP/DIR tanggal 14 Mei 1999 tentang Persyaratan dan Tata Cara Merger, Konsolidasi dan Akuisisi Bank Perkreditan Rakyat.

Dalam praktiknya penggabungan dalam dunia perbankan tidak hanya bagi bank yang dinilai tidak sehat saja, akan tetapi bank yang sehat pun dapat pula bergabung dengan bank lainnya sesuai dengan tujuan bank tersebut. Sebagai contoh bank dapat bergabung dengan tujuan untuk menguasai pasar. Namun biasanya penggabungan antar bank yang tidak sehat lebih diutamakan. ${ }^{15}$

\section{Perlindungan Para Pihak dalam Merger Bank a. Kepentingan Para Pemegang Saham}

Para pemegang saham harus menerima appraisal remedy-nya atau appraisal rights-nya. ${ }^{16}$ Bila appraisal remedy dan appraisal rights dari pemegang saham tidak dijamin, maka keputusan perseroan yang merugikan para pemegang saham akan dapat menimbulkan sengketa, yang tidak mustahil akan berupa proses litigasi atau gugatan di pengadilan sebagaimana diatur pada Pasal 61 UUPT. Sengketa bisa timbul terutama jika merger saham itu merupakan tindakan Bank Indonesia untuk menyelamatkan atas bank yang bermasalah. Sebab, harus diingat bahwa yang dikenai oleh Bank Indonesia itu adalah "bank-nya" sebagai suatu business entity, dan bukan para pemegang sahamnya sebagai pribadi. ${ }^{17}$ Kesalahan yang dilakukan, baik karena kesengajaan ataupun kelalaian, sampai terpaksa bank tersebut mengalami kesulitan yang membahayakan usahanya, bukan merupakan

\footnotetext{
${ }^{15}$ Canciones de Manuales, Ciri-ciri Bank Sehat, buscar-manuales.com/ciri-ciri-banksehat.html diakses tanggal 2 April 2016.

${ }^{16}$ Prinsip appraisal remedy dan appraisal rights adalah hak dari pemegang saham minoritas yang tidak setuju terhadap merger (tetapi dia kalah suara) atau terhadap tindakan-tindakan koorporat lainnya, untuk menjual saham yang dipegangnya itu kepada perusahaan yang bersangkutan, di mana pihak perusahaan yang mengisukan saham tersebut wajib membeli kembali saham-sahamnya dengan harga yang pantas.

${ }^{17}$ Op.Cit., Adrian Sutedi, hlm. 118.
} 
tindakan pemegang saham, tetapi merupakan tindakan manajemen bank yang bersangkutan (Direksi dan Dewan Komisaris). ${ }^{18}$

Sehubungan dengan hal tersebut, maka pemegang saham tidak bisa dipaksakan untuk menerima begitu saja harga yang ditawarkan oleh bank yang akan mengambil alih (Pasal 62 UUPT). Namun, di pihak lain memang harus pula disadari oleh para pemegang saham bahwa apabila merger saham tidak sampai terjadi, maka Bank Indonesia dapat mencabut izin usaha bank tersebut. Dalam hal terjadi demikian maka pemegang saham tidak akan memperoleh apa-apa kecuali sisa harta likuidasi setelah dibagi-bagikan kepada kreditor-kreditor lain dari bank itu berdasarkan prioritasnya.

Perlindungan terhadap pemegang saham, terutama pemegang saham minoritas sangat penting dalam hukum merger, di samping perlindungan pihak-pihak lainnya seperti pihak karyawan perusahaan. Dalam merger Kode Belanda misalnya, bahkan didalamnya diatur tiga pokok permasalahan sebagai berikut: Bab I: Mengatur tentang perlindungan pemegang saham (berlaku khusus untuk penawaran umum saham); Bab II: Mengatur tentang perlindungan karyawan. Bahkan untuk perusahaan yang memunyai minimal 100 (seratus) orang karyawan, usaha untuk merger haruslah berkonsultasi dengan trade union Bab III: Mengatur tentang informasi (tentang merger) yang diperlukan oleh Menteri Ekonomi di sana.

Dalam upaya perlindungan pemegang saham minoritas, prinsip one share one vote sebenarnya juga telah diatur dalam Undang-Undang No. 4 Tahun 1971, yang mengubah Pasal 54 KUHD. Prinsip ini menempatkan pihak pemegang saham minoritas sebagai pihak yang rawan ekploitasi. Hanya dalam hal-hal tertentu saja, yakni dalam hal yang termasuk dengerous area, diberikan perhatian khusus oleh hukum untuk melindungi pemegang saham minoritas. Perlindungan pemegang saham minoritas dalam hal seperti ini dilakukan dengan memperkenalkan prinsip special vote, yang operasionalnya minimal dilakukan dengan dua cara sebagai berikut; ${ }^{19} 1$ ) Prinsip silent majority, yaitu pemegang saham diwajibkan abstain dalam voting; 2) Prinsip uper majority, yaitu dalam hal ini dilakukan RUPS menyaratkan pemberlakuan voting $2 / 3$ suara, keputusan dari rapat tidak bisa diambil jika suara yang setuju kurang dari persentase tersebut.

\section{b. Kepentingan Para Nasabah Penyimpan Dana}

Bukan saja dalam hal merger, konsolidasi atau akuisisi saham yang terjadi sukarela, tetapi dalam hal merger, konsolidasi atau akuisisi itu merupakan tindakan Bank Indonesia untuk melakukan penyelamatan bank yang bermasalah, justru terutama kepentingan nasabah penyimpan dana dari

\footnotetext{
${ }^{18}$ Ibid.

${ }^{19}$ Munir Fuady, Hukum Perbankan Modern, (Bandung: Citra Aditya Bakti, 1999), hlm. 130.
} 
bank yang ditugasi untuk mengambil alih tidak boleh dirugikan, bahkan apabila memungkinkan diuntungkan dengan tindakan tersebut. ${ }^{20} \mathrm{Hal}$ ini dijamin oleh Pasal 126 ayat (1) UUPT yang menentukan bahwa perbuatan hukum penggabungan, penggabungan, pengambilalihan, atau pemisahan wajib memperhatikan kepentingan; a) perseron, pemegang saham minoritas, karyawan Perseroan; b) kreditor dan mitra usaha lainnya dari Perseroan; dan c) masyarakat dan persaingan sehat dalam melakukan usaha.

Kepentingan nasabah penyimpan dana dari suatu bank yang akan mengambil alih, besar kemungkinan akan menghadapi bahaya dalam hal banknya melakukan merger atau konsolidasi dengan bank lain. Sering merger atau konsolidasi tidak menghasilkan apa yang diharapkan. Seringkali merger menimbulkan kesulitan pada bank yang mengambil alih. Implementasi merger yang tidak baik, akan menyebabkan kelangsungan hidup dari bank yang mengambil alih setelah melakukan merger atau konsolidasi, menjadi terseok-seok. Kesulitan lain dapat timbul karena tidak diketahuinya secara pasti dan tepat jenis dan besarnya masalah yang tersembunyi (hidden problem), termasuk pertanggungjawaban dari bank yang menjadi sasaran merger.

Juga benturan dari kedua budaya perusahaan yang tidak dapat berasimiliasi dengan baik, antara lain sistem akuntansi, kepegawaian, perkreditan, treasury. ${ }^{21}$ Belum lagi terjadinya demoralisasi dan demotivasi dari para pegawai yang diambil alih, terutama di tingkat manajer akan sangat mengganggu pula jalannya bank yang mengambil alih setelah terjadinya merger. Maka dari itu, kepentingan nasabah dari bank yang menjadi sasaran merger harus pula diperhatikan sebagaimana hal itu diharuskan pada Pasal 126 ayat (1) huruf a UUPT.

\section{c. Kepentingan Para Pegawai Bank}

Tergusurnya beberapa staf, baik dari bank target maupun dari bank pengambil alih untuk menurunkan biaya overhead akan menimbulkan masalah baru. Dalam merger ini biasanya karyawan atau staf dari bank yang dilikuidasi masuk menjadi staf atau karyawan bank target (bank yang dilanjutkan). Konsekuensi dari masuknya karyawan tersebut, ia harus tunduk pada aturan yang berlaku pada bank target. Apabila keberatan, ada dua alternatif yang diberikan, yaitu mengundurkan diri atau pindah kepada perusahaan lain dalam grupnya. Perlindungan terhadap tenaga kerja dari perusahaan yang diambil alih juga penting. ${ }^{22}$

\footnotetext{
${ }^{20}$ Op. Cit., Adrian Sutedi, hlm. 124.

${ }^{21}$ Ibid.

${ }^{22}$ Ibid., hlm. 125.
} 
Secara spesifik pula, Pasal 126 ayat (1) UUPT menghendaki agar perbuatan hukum penggabungan, penggabungan, pengambilalihan, atau pemisahan wajib memperhatikan kepentingan karyawan perseroan, baik karyawan dari bank yang mengambil alih maupun dari bank yang menjadi sasaran. Tidak diperhatikannya kepentingan karyawan perseroan dan sebagai akibat karyawan dirugikan dapat memberikan hak bagi karyawan yang dirugikan itu untuk menggugat perseroan berdasarkan Pasal 1365 KUH Perdata yang mengatur mengenai perbuatan melawan hukum. Pasal 1365 KUH Perdata menegaskan bahwa "Tiap perbuatan melanggar hukum yang membawa kerugian kepada orang lain, mewajibkan orang yang karena salahnya menerbitkan kerugian itu, mengganti kerugian tersebut".

Beberapa hal yang harus diperhatikan sehubungan dengan kepentingan para pegawai bank adalah: ${ }^{23}$

1) prinsip-prinsip umum mengenai kebijaksanaan kesejahteraan sosial yang akan diterapkan setelah merger

2) waktu yang pantas untuk berkonsultasi dengan organisasi pegawai bank

3) cara dan saat untuk meninformasikan merger kepada pegawai bank

4) cara untuk mencegah atau setidak-tidaknya mengeliminasi kemungkinan kerugian materiil kepada pihak pegawi, termasuk memberikan kompensasi yang bersifat materiil.

5) aktivitas khusus dari organisasi pekerja dalam perusahaan.

6) suatu garansi terhadap keamanan dan ketersediaan pekerjaan setelah merger.

Dalam kasus-kasus merger dan akuisisi, seringkali dengan alasan peningkatan efisiensi dan perampingan usaha, setelah merger dan akuisisi sebagian karyawan/pekerja diputuskan untuk di PHK. Pihak pekerja menurut sistem hukum kita hampir-hampir tidak punya upaya hukum apapun menolak PHK tersebut. Karena itu, asalkan PHK tersebut dilaksanakan sesuai dengan ketentuan peraturan perundang-undangan yang berlaku, maka pelaksanaan PHK tersebut sudah sah. Namun jika dalam pelaksanaan merger yang dilakukan oleh Bank tidak bermaksud untuk melakukan pemutusan kerja dan oleh karenanya tidak akan memberikan paket pesangon, namun tetap memperhatikan peraturan perundang-undangan ketenagakerjaan mengenai kompensasi dalam hal ada karyawan yang ingin mengundurkan diri, dengan sebelumnya meminta untuk menandatangani surat pengunduran diri bagi pihak karyawan yang tidak ingin bergabung, yang dibuat sama dengan tanggal efektif penggabungan.

Pada beberapa negara tertentu ada peraturan yang menyaratkan beralihnya setiap kontrak kerja atas atau kesepakatan kerja bersama dari perusahaan yang dilebur kepada perusahaan yang melakukan merger by the

${ }^{23}$ Ibid., hlm. 126. 
operation of law (demi hukum). Dua hal tersebut berlaku secara otomatis, sungguhpun tidak disebut-sebut dalam perjanjian merger dan akuisisi. Di Indonesia kita belum memunyai aturan seperti itu. Bahkan ketentuan perburuhan kita memperbolehkan pemutusan hubungan kerja terhadap para pekerja, asal dilakukan dengan prosedur dan syarat-syarat yang sesuai dengan hukum yang berlaku. Alasannya bisa saja misalnya untuk meningkatkan efisiensi perusahaan.

Selain itu, juga benar di negara-negara tertentu diperkenankan partisipasi serikat kerja di perusahaan yang bersangkutan dalam proses merger dan akuisisi. Dan itu sudah selangkah lebih maju. Namun demikian, keputusan akhir tentu tetap berada pada pihak pemegang saham, sebagai pemegang kekuasaan tertinggi.

\section{d. Kepentingan Para Pengurus}

Dalam proses merger saham yang terjadi secara sukarela atau secara wajar, memang kepentingan pengurus tidak dapat diabaikan. Namun dalam hal merger terjadi sebagaimana dimaksudkan dalam Pasal 37 UndangUndang No. 10 Tahun 1998 tentang Perubahan atas Undang-Undang No. 7 Tahun 1992 tentang Perbankan, maka pada hakikatnya itu adalah tindakan yang diambil oleh Bank Indonesia sebagai konsekuensi dari kesalahan pihak pengurus. Oleh karena itu, kepentingan mereka boleh, bahkan justru harus diabaikan sebagai tebusan atas kesalahan mereka sendiri.

\section{Penutup}

Merger merupakan salah satu pengembangan dan pertumbuhan perusahaan. Merger juga merupakan salah satu alternatif lain untuk melalui investasi modal pertumbuhan secara internal dan organis. Dalam perbankan merger diatur pada Undang-Undang No 10 Tahun 1998 tentang Perbankan, selain itu diatur juga pada PP No. 28 Tahun 1999 tentang Merger, Konsolidasi dan Akuisisi Bank dan Surat Keputusan Bank Indonesia Nomor 32/51/KEP/DIR tanggal 14 Mei 1999 tentang Persyaratan dan Tata Cara Merger, Konsolidasi dan Akuisisi Bank Umum, serta Surat Keputusan Bank Indonesia Nomor 32/52/KEP/DIR tanggal 14 Mei 1999 tentang Persyaratan dan Tata Cara Merger, Konsolidasi dan Akuisisi Bank Perkreditan Rakyat. Undang-Undang Perbankan mengenal dua macam merger saham bank, yaitu secara sukarela dan imperatif. Berdasarkan Pasal 28 Undang-Undang Nomor 10 Tahun 1998 tentang Perbankan, mengatur mengenai merger sukarela. Sedangkan Pasal 37 ayat 2 mengatur mengenai merger imperatif. Berdasarkan Pasal 28 ayat 1 menyatakan bahwa merger, konsolidasi dan akuisisi wajib dahulu mendapat izin Pimpinan Bank Indonesia. Mengingat ketentuan Pasal 10 jo. Pasal 7 huruf b dan c UU Perbankan, bank hanya 
boleh melakukan merger dan konsolidasi dengan perseroan yang berupa bank saja dan hanya boleh melakukan akuisisi perseroan bank dan perusahaan lain sepanjang usahanya di bidang keuangan. Dalam pelaksanaannya merger harus memperhatikan kepentingan para pihak. Para pihak tersebut wajib diberikan perlindungan terhadap kepentingannya apabila bank melakukan merger. Para pihak yang memiliki kepentingan tersebut yaitu, 1) kepentingan para pemegang saham, 2) kepentingan para nasabah penyimpan dana, 3) kepentingan para pegawai bank, dan 4) kepentingan para pengurus.

\section{Daftar Pustaka}

\section{A. Buku}

Black, Henry Campbell, 1991, Black's Law Dictionary, St. Paul Minn: West Publishing Co.

Daryanto, Agus, 2004, Meger Bank Indonesia (Beserta Akibat-Akibat Hukumnya), Bogor: Ghalia Indonesia.

Fuady, Munir, 1999, Hukum Perbankan Modern, Bandung: Citra Aditya Bakti.

, 1999, Hukum Tentang Merger, Cetakan ke-I, Bandung: PT. Citra Aditya Bakti

Irawan dan M. Suparmoko, 1992, Ekonomi Pembangunan, Yogyakarta: BPFE Yogyakarta.

M. Echols, John dan Shadily, Hassan 1990, Kamus Inggris-Indonesia, Cetakan XIX, Jakarta: PT.Gramedia.

PS. Sudarsanam, 1995, The Essence of Mergers and Acquistions, Prentice Hall Europe Ltd.

Remy Sjahdeini, Sutan, Tanpa Tahun, Merger Konsolidasi dan Akuisisi Bank, Tidak Dipublikasikan.

Riyanto, Bambang, 1989, Dasar-Dasar Perusahaan, Yogyakarta: Yayasan Badan Penerbit Gadjah Mada

Simanjuntak, Cornelius dan Mulia, Natalie 2006, Merger Perusahaan Publik, Bandung: PT Citra Aditya Bakti.

Sutedi, Adrian, 2007, Hukum Perbankan, Jakarta: Sinar Grafika.

\section{B. Peraturan Perundang-undangan}

Kitab Undang-Undang Hukum Perdata.

Undang-Undang Nomor 10 Tahun 1998 tentang Perbankan.

Peraturan Pemerintah Nomor 28 Tahun 1999 tentang Merger, Konsolidasi dan Akuisisi Bank. 
Surat Keputusan Bank Indonesia Nomor 32/51/KEP/DIR tanggal 14 Mei 1999 tentang Persyaratan dan Tata Cara Merger, Konsolidasi dan Akuisisi Bank Umum.

Surat Keputusan Bank Indonesia Nomor 32/52/KEP/DIR tanggal 14 Mei 1999 tentang Persyaratan dan Tata Cara Merger, Konsolidasi dan Akuisisi Bank Perkreditan Rakyat.

\section{Lain-lain}

Manuales, Canciones de, Ciri-Ciri Bank Sehat, buscar-manuales.com/ciriciri-bank-sehat.html 